\title{
Anatomical and Functional Description of the Radius of White Footed Tamarin (Saguinus leucopus)
}

\author{
Descripción Anatómica y Funcional del Radio del Tamarino Manos Blancas (Saguinus leucopus)
}

\author{
Jorge Eduardo Duque Parra*,**; Juan Fernando Vélez García**** \& John Barco Ríos*
}

\begin{abstract}
DUQUE, P. J. E.; VÉLEZ, G. J. F. \& BARCO, R. J. Anatomical and functional description of the radius of white footed tamarin (Saguinus leucopus). Int. J. Morphol., 32(3):914-917, 2014.

SUMMARY: Saguinus leucopus is a neotropical primate, endemic and monotypic of Colombia (South America), with few studies of its anatomy, whose morphology radius this key element of this quadruped locomotion arboreal animal remains unknown. This study describes the gross functional anatomy of the radius bone of white-footed tamarin (Saguinus leucopus). The study was based on eight specimens fixed with $10 \%$ formalin and extracted their radius them, describing the main features of the bony prominences, such as muscle and ligaments attachments and neurovascular pipes. The radius of Saguinus leucopus bony presents some prominences for muscles and ligaments attachments, in addition to the synovial cartilage regions to other parts of the forelimb. The various anatomical contours of the radius of Saguinus leucopus exhibit characteristics typical particular motor functions adapted to the environment of an arboreal quadruped position.
\end{abstract}

KEY WORDS: Radius; Anatomy; Function; Primate; Saguinus; Morphology.

\section{INTRODUCTION}

The white-footed tamarin (Saguinus leucopus) is a neotropical primate, endemic and monotypic of Colombia, whose posture and quadrupedal locomotion you get around mainly with jumps and adhere to branches and trunks of trees (Defler, 2010). These primates depend mainly fruits for sustenance and thus must climb (Strier, 1992), as well as to explore their various recesses, requiring behaviors position to manipulate, and eating food and escape of potential predators (Garber, 2007), behaviors that are always the end result of the integration of muscle contractions (Tinbergen, 1969). Therefore, the study of animal locomotion is essential to understanding its adaptation (Youlatos \& Meldrum, 2011), and this is derived from locomotor system, which includes support forearm bone, thereby characterizing anatomofunctional of the radius can provide relevant information, since one of the central insights of vertebrates are the functional consequences attending skeletal morphological diversity (Ross, 2005). In primates the diverse and complex ways must be sought to understand their relationship with the function (Reindenberg, 2007) even evolutionarily, as in the case of highly modified appendicular osteology aquatic mammals (Cooper et al., 2007), in the forearm of cetaceans such as whales, dolphins and porpoises have been changed radically during the transition from planar member to paddle (Cooper et al.). Although the shape of the distal radius is largely similar existing hominids except humans (Tallman, 2012), has certain differences in some primates that are quadrupeds (Yamanaka et al., 2005) as Macaca mulatta who is terrestrial primate and Macaca fasicularis an arboreal primate (Kikuchi \& Hamada, 2009).

The radius at it's distal provides little evidence that early hominids evolved from an ancestor that walked on his knuckles (Tallman), but studies have allowed radius morphomecanic detailing changes in muscle attachment sites, tendon and ligamentous taking into account the various bony prominences (Galtés et al., 2006), as tubers, ridges and head, among others, allowing anatomists (Somesh et al., 2011) and other professionals to have a better understanding of this forelimb bone. Studies of the anatomy of the white-footed tamarin are rare (Stevenson et al., 2010), hence the importance of having a clear understanding of their anatomical features that contribute to the functional significance (Aversi-Ferreira et al., 2005) for clinical and

\footnotetext{
* Programa de Medicina. Departamento de Ciencias Básicas. Universidad de Caldas, Manizales, Colombia.

*** Departamento de Ciencias Básicas Biológicas. Universidad Autónoma, Manizales, Colombia.

**** Programa de Medicina Veterinaria y Zootecnia. Departamento de Salud Animal. Universidad de Caldas, Manizales, Colombia.
} 
surgical procedures. This anatomical knowledge will also serve to explain, in general, how early hominids were adapted for a wide variety of locomotives postures (Tallman), approaching the various adaptations (Aversi-Ferreira et al.) of primates to their environment, which in this case correspond to a branch of nonhuman primates that occupy a wide range of habitats in America, from Mexico to Argentina (Youlatos \& Meldrum), including Colombia. The study of radius of Saguinus leucopus contributes to understanding locomotion intra-specific and comparative analysis with other species.

\section{MATERIAL AND METHOD}

Eight specimens of white-footed tamarin (Saguinus leucopus) were used, four females and four males weighing between 300 and 460 $\mathrm{g}$, who died of natural causes between 2012 and the first quarter of 2013, in the centers and wildlife assessment of CORPOCALDAS (Colombia). Infiltrations were fixed by subcutaneous, intramuscular and cavities with a solution of $10 \%$ formalin, $5 \%$ mineral oil and $1 \%$ carbolic acid. The specimens were immersed in the same solution for a minimum period of 48 hours. They performed dissections of the forearm from the plane surface of the deep, and photographic records were kept of the proceedings in which it emphasized the functional anatomy of the radius. The anatomical findings were described according to the terminology of Veterinary Anatomical Payroll 2012 (ICVGAN, 2012) and the 1998 International Anatomical Terminology (FICAT, 1998).

\section{RESULTS AND DISCUSSION}

In the radius of Saguinus leucopus bony prominences were found for muscle and ligament attachments, in addition to the synovial cartilage regions to other parts of the forelimb, we assume in the self-description of quadrupeds. The radius occupies an oblique position, where its proximal epiphysis is in cranial-lateral position, while his shaft and distal epiphysis are cranial-medial position. In its proximal epiphysis is recognized elliptical head, at whose end locates a fovea to articulate with humeral condyle head, allowing flexion and forearm rotation. The head is surrounded by the annular ligament fixation and joins it articulation with the ulna. Immediately distal to the joint circumference is the radial neck. At the proximal end of the shaft, near the neck of the epiphysis, there is a prominent bone: a tuberosity on the caudal lateral face in which a groove is formed for attachment of biceps brachial muscle. The shaft of the radius has a shape elongated in which there are three sides, one side and a flat head and a rounded medial and three edges, a blunt head, one corresponding to sharp flow edge which is fixed interosseous membrane, which is partly translucent, partly ligamentous, where the latter forms a greater prominence of this edge in its proximal portion and a third medial border, posing in the middle third of a rough surface for the insertion of the pronator teres muscle (Figs. 1-3).

From tuberosity shows an oblique line that reaches the medial border on attachment the supinator muscle. In the distal epiphysis is recognized very sharp styloid process, which continues in a proximal direction, and a short drive from its medial border, with a crest well developed and acute supra-styloid process where brachioradialis muscle is attachment (Figs. 1 and 2). Among them and their cranial face a groove is formed by coursing the tendon of abductor longus muscle. No there is a notch, at least obvious to articulate with the head of the ulna. In the central region of the cranial face of the distal epiphysis presents a way of bony tubercle, and on each side of this short run two rows, one medial for the passage of the tendons of the extensor carpi radialis longus and extensor carpi radialis brevis muscles, and one lateral to the extensor tendons pass deep first and second fingers, while on its face has a surface

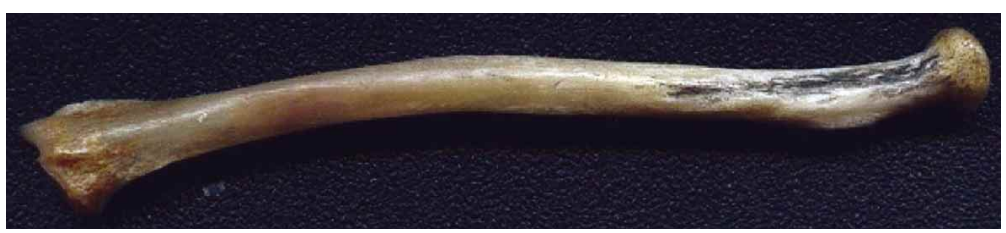

Fig. 1. Cranial view of the left radius of S. leucopus

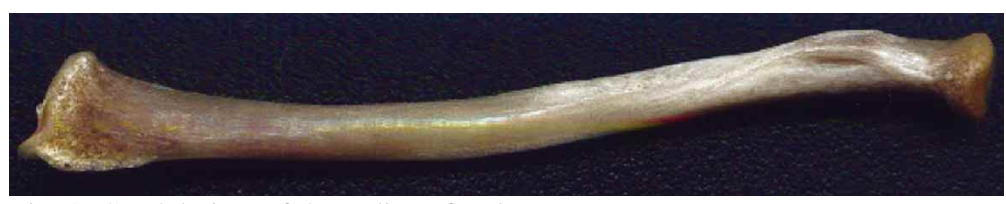

Fig. 2. Caudal view of the radius of S. leucopus.

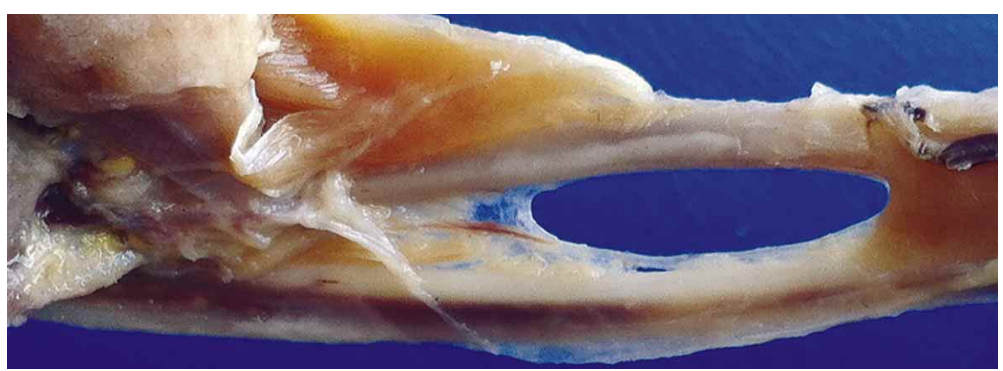

Fig. 3. View of the interosseous membrane between the interosseous edges of radius and ulna. 
flow for the insertion of pronator quadrates muscle. Finally, at the end of the epiphysis is a slight concavity to form the articular surface of the carpus.

Similar findings to ours have been described in the proximal epiphysis of the radius of $S$ oedipus, a species of the same genus as the $S$ leucopus, a pattern similarly as quadrupedal arboreal locomotion (Ackermann, 2003). A species of primate quadrupedal locomotion, such as Galago senegalensis presents a proximal epiphysis more cranial that the human radius (Stevens et al., 1977), and also has a provision similar to that found by us in S. leucopus. Consistent with the shape of the distal radius noticed that, as already indicated, is largely similar across existing hominids (Tallman), although the $S$ leucopus found individual features such as the development of a ridge suprastyloid. Studies in the radius of different primate species have been determined to prominence for the insertion of the brachioradialis muscle is very pronounced in Cebus, Lemur and Galago, and also in some Cynopithecinae (Mivart, 1867), similar to $S$. leисориs which by their, define as crest morphology.

\section{CONCLUSIONS}

The various bony prominences of the radius of whitefooted tamarin (Saguinus leucopus), among which stands out the fovea radial articular circumference, radial tuberosity, styloid process, supra-styloid crest and grooves for various tendons, show a striking resemblance to human radius, but in the radius of the Titi gray, some reliefs and edges are more developed and notorious, which suggests that facilitate better integration sinewy and fleshy origin for those muscles that develop motor functions in accordance with the environment in which they operate as to jump and attached to the trunks and branches of trees in quadruped position.

DUQUE, P. J. E.; VÉLEZ, G. J. F. \& BARCO, R. J. Descripción anatómica y funcional del radio del tamarino manos blancas (Saguinus leucopus). Int. J. Morphol., 32(3):914-917, 2014.

Saguinus leucopus es un primate neotropical, endémico y monotípico de Colombia, con escasos estudios sobre su anatomía, y por ende de la morfología radial, elemento fundamental para la locomoción cuadrúpeda de este animal arbóreo que permanece desconocida. El objetivo fue describir la anatomía macroscópica y funcional de los relieves óseos del radio del titi gris (Saguinus leucopus). Se tomaron como base del estudio ocho especímenes fijados con formalina al 10\% y de ellos se extrajeron sus radios, describiendo completamente su anatomía macroscópica. Los principales relieves óseos con sus funciones de fijación muscular y ligamentosa, y canalizaciones neurovasculares. El radio del Saguinus leucopus presenta algunas prominencias óseas fijaciones musculares y ligamentosas, además presenta regiones de cartílago sinovial para articular con otras partes del miembro anterior. Los variados relieves anatómicos del radio del Saguinus leucopus presentan características típicas particulares, adaptadas a funciones motoras para su ambiente propio de una posición arbórea cuadrúpeda.

PALABRAS CLAVE: Radio; Anatomía; Función; Primate; Saguinus; Morfología.

\section{REFERENCES}

Ackermann, R. R. A comparative primate anatomy. Dissection manual. University of Capetown, 2003. Disponible en: http:// web.uct.ac.za/depts/age/people/dissect.pdf

Aversi-Ferreira, T. A.; Roqueline, A. G.; Aversi-Ferreira, R. A.; Silva, Z.; Gouvêa-E-Silva, L. F. \& Penha-Silva, N. Estudo anatômico de músculos profundos do antebraço de Cebus apella (Linnaeus, 1766). Acta Sci. Biol. Sci., 27(3):297-301, 2005.

Cooper, L. N.; Dawson, S. D.; Reidenberg, J. S. \& Berta, A. Neuromuscular anatomy and evolution of the cetacean forelimb. Anat. Rec. (Hoboken), 290(9):1121-37, 2007.

Defler, T. R. Historia Natural de Primates Neotropicales. Bogotá, Universidad Nacional de Colombia, 2010.
Federative International Committee on Anatomical Terminologies (FICAT). Terminologia Anatomica. International Anatomical Terminology. New York, Thieme, 1998.

Garber, P. A. Primate locomotor behavior and ecology. En: Campbell, C.; Fuentes, A.; MacKinnon, K. C.; Panger, M. \& Bearder, S. (Eds.). Primates in perspective. Oxford, Oxford University Press, 2007.

International Committee on Veterinary Gross Anatomical Nomenclature (ICVGAN). Nomina Anatomica Veterinaria. Hannover, World Association of Veterinary Anatomists, 2012.

Kikuchi, Y. \& Hamada, Y. Geometric characters of the radius and tibia in Macaca mulatta and Macaca fascicularis. Primates, 50(2):169-83, 2009. 
Galtés, I.; Rodríguez-Baeza, A. \& Malgosa, A. Mechanical morphogenesis: a concept applied to the surface of the radius. Anat. Rec. A Discov. Mol. Cell. Evol. Biol., 288(7):794-805, 2006.

Mivart, G. On the appendicular skeleton of the primates. Philos. Trans. R. Soc. Lond., 157:299-429, 1867.

Reidenberg, J. S. Anatomical adaptations of aquatic mammals. Anat. Rec. (Hoboken), 290(6):507-13, 2007.

Ross, C. F. Finite element analysis in vertebrate biomechanics. Anat. Rec. A Discov. Mol. Cell. Evol. Biol., 283(2):253-8, 2005.

Somesh, M. S.; Prabhu, L. V.; Shilpa, K.; Pai, M. M.; Krishnamurthy, A. \& Murlimanju, B. V. Morphometric study of the humerus segments in Indian Population. Int. J. Morphol., 29(4):1174-80, 2011.

Stevens, J. L.; Meyer, D. M. \& Edgerton, V. R. Gross anatomy of the forelimb and shoulder girdle of the Galago senegalensis. Primates, 18(2):435-52, 1977.

Stevenson, P. R.; Guzmán, D. C. \& Defler, T. R. Conservation of Colombian primates: an analysis of published research. Trop. Conserv. Sci., 3(1):45-62, 2010.

Strier, K. B. Atelinae adaptations: behavioral strategies and ecological constraints. Am. J. Phys. Anthropol., 88(4):515-24, 1992.

Tallman, M. Morphology of the distal radius in extant hominoids and fossil hominins: implications for the evolution of bipedalism. Anat. Rec. (Hoboken), 295(3):454-64, 2012.

Tinbergen, N. El estudio del instinto. México D.F., Siglo Veintiuno Editores, 1969.

Yamanaka, A.; Gunji, H. \& Ishida, H. Curvature, length, and crosssectional geometry of the femur and humerus in anthropoid primates. Am. J. Phys. Antrophol., 127(1):46-57, 2005.

Youlatos, D. \& Meldrum, J. Locomotor diversification in new world monkeys: running, climbing, or clawing along evolutionary branches. Anat. Rec. (Hoboken), 294(12):1991-2012, 2011.

\section{Correspondence to: \\ Jorge Eduardo Duque Parra \\ Programa de Medicina \\ Universidad de Caldas \\ Manizales. \\ COLOMBIA}

Email: jorge.duque_p@ucaldas.edu.co

Received: 08-09-2013

Accepted: 28-05-2014 